\title{
Penerapan Kegiatan Bimbingan Berkelanjutan dalam Meningkatkan Kemampuan Guru Budang Studi dalam Menyusun Perangkat Pembelajaran di SMP Negeri 2 Sampoiniet Tahun Pelajaran 2019/2020
}

\author{
Hafsah, S.Pd \\ SMP Negeri 2 Sampoiniet
}

\begin{abstract}
Abstrak
Perangkat Pembelajaran Seperti Silabus, RPP, Media Pembelajaran, Bahan Ajar, dan lai sebagainya merupakan salah satu pokok administras guru dari beberapa komponen lainnya dalam proses pembelajaran. Kelemahan dalam menyusun perangkat tersebut sering terjadi pada saat sebelum proses pelaksanaan pembelajaran, dengan demikian dalam menyusun dan merancang perangkat tersebut diharapkan benar-benar efesien dan bermakna. Setelah melakukan supervisi perlu dilakukan perubahan oleh setiap guru dalam menyusun perangkat pembelajaran yang sesuai dengan materi yang diajarkan. PTS ini dilakukan dalam 2 (dua) siklus. Penelitian ini dilaksanakan pada bulan November s.d Desember 2019 di SMP Negeri 2 Sampoiniet yang berjumlah 3 orang guru bidang Study yang terdiri dari 1 Guru PJOK, 1 guru PAI, dan 1 guru PKn. Untuk pengumpulan data peneliti menggunakan bimbingan berkelanjutan yang berkelanjutan. Pengolahan data dilakukan dengan wawancara, pengamatan, dan observasi terhadap penyusunan perangkat pembelajaran oleh setiap guru bidang study. Berdasarkan penelitian ada peningkatan kemampuan guru dalam menyusun perangkat pembelajaran yang efektif sehingga proses pembelajaran lebih bermakna dan bermutu seperti yang diharapkan
\end{abstract}

\section{Kata kunci : Bimbingan, Kemampuan Guru, Perangkat Pembelajaran}

\section{PENDAHULUAN}

Perencanaan pembelajaran merupakan langkah yang sangat penting sebelum pelaksanaan pembelajaran. Perencanaan yang matang diperlukan supaya pelaksanaan pembelajaran berjalan secara efektif. Perencanaan pembelajaran dituangkan ke dalam perangkat pembelajaran atau beberapa istilah lain seperti desain pembelajaran, skenario pembelajaran dan lain sebagainya. Perangkat Pembelajaran memuat tingkat pencapaian perkembangan, indikator yang akan dicapai, materi yang akan dipelajari, metode pembelajaran, langkah pembelajaran, media pembelajaran, dan sumber belajar serta penilaian.

Guru harus mampu berperan sebagai desainer (perencana), implementor (pelaksana), dan evaluator (penilai) kegiatan pembelajaran. Guru merupakan faktor yang paling dominan karena di tangan gurulah keberhasilan pembelajaran dapat dicapai. Kualitas mengajar guru secara langsung maupun tidak langsung dapat mempengaruhi kualitas pembelajaran pada umumnya. Seorang guru dikatakan profesional apabila (1) serius melaksanakan tugas profesinya, (2) bangga dengan tugas profesinya, (3) selalu menjaga dan berupaya meningkatkan kompetensinya, (4) bekerja 
dengan sungguh tanpa harus diawasi, (5) menjaga nama baik profesinya, (6) bersyukur atas imbalan yang diperoleh dari profesinya.

Peraturan Pemerintah Nomor 19 Tahun 2005 tentang 8 Standar Nasional Pendidikan menyatakan standar proses merupakan salah satu SNP untuk satuan pendidikan dasar dan menengah yang mencakup: 1) Perencanaan proses pembelajaran, 2) Pelaksanaan proses pembelajaran, 3) Penilaian hasil pembelajaran, 4) dan pengawasan proses pembelajaran

Perangkat pembelajaran dikembangkan oleh guru pada satuan pendidikan . Guru pada satuan pendidikan berkewajiban menyusun silabus, Perangkat Pembelajaran secara lengkap dan sistematis agar pembelajaran berlangsung secara interaktif, inspiratif, menyenangkan, menantang, memotivasi peserta didik untuk berpartisipasi aktif, serta memberikan ruang yang cukup bagi prakarsa, kreativitas, dan kemandirian sesuai dengan bakat, minat dan perkembangan fisik serta psikologis peserta didik.

Berdasarkan konsep dasar pengembangan kurikulum 2013 revisi 2017, ada tiga hal pokok yang akan dicapai dalam pembelajaran, yakni karakter, kompetensi, dan literasi. Ketiga hal tersebut ditanamkan secara terpadu untuk membangun kompetensi peserta didik yang seimbang antara aspek sikap, pengetahuan, dan keterampilan. Sejalan dengan upaya pencapaian tiga hal tersebut, beberapa komponen pendukung ketercapaian pembelajaran perlu dirancang secara efektif dengan berdasar pada analisis kebutuhan peserta didik pada zamanya. Komponen-komponen tersebut antara lain kurikulum, pembelajaran, perbukuan, dan penilaian. Realisasi dari penerapan keempat hal tersebut akan dapat dilihat secara terpadu melalui rancangan pelaksanaan pembelajaran yang disusun oleh guru dalam bentuk RPP. Penyusunan RPP menjadi salah satu tanggung jawab guru yang menjadi motor penggerak dalam pelaksanaan pembelajaran. Idealnya, RPP merupakan potret riil pembelajaran yang akan dilaksanakan oleh guru. Dalam hal ini, RPP merupakan rancangan pembelajaran mulai dari awal pembelajaran sampai dengan penilaian akhir. Oleh karena itu, dapat dikatakan bahwa pemahaman guru dalam menerapkan kurikulum 2013 revisi 2017 dapat dilihat dari bagaimana guru menyusun RPP.

Pada komponen penilaian (penskoran) sebagian besar guru tidak lengkap membuatnya dengan alasan sudah tahu dan ada di kepala. Sedangkan pada komponen tujuan pembelajaran, materi ajar, metode pembelajaran, dan sumber belajar sebagian besar guru sudah membuatnya.

Masalah yang lain yaitu sebagian besar guru khususnya di sekolah swasta belum mendapatkan pelatihan pengembangan perangkat pembelajaran . Selama ini guru-guru yang mengajar di sekolah negeri/swasta sedikit atau jarang mendapatkan kesempatan untuk mengikuti berbagai Diklat Peningkatan Profesionalisme Guru. Hal ini menyebabkan banyak guru yang belum tahu dan memahami penyusunan/pembuatan perangkat pembelajaran secara baik/lengkap. Beberapa guru mengadopsi perangkat pembelajaran orang lain. Hal ini peneliti ketahui pada saat mengadakan supervisi akademik (supervisi kunjungan kelas) ke sekolah binaan. Permasalahan tersebut berpengaruh besar terhadap pelaksanaan proses pembelajaran.

Berdasarkan uraian latar belakang di atas maka penulis tertarik untuk mengadakan penelitian yang akan dituangkan dalam sebuah bentuk tulisan laporan penelitian tindakan sekolah dengan judul "Penerapan kegiatan bimbingan berkelanjutan 
dalam meningkatkan kemampuan guru bidang study dalam menyusun perangkat pembelajaran di SMP Negeri 2 Sampoiniet Kecamatan Sampoiniet Kabupaten Aceh Jaya Tahun Pelajaran 2019/2020”.

\section{Tujuan Penelitian}

Tujuan dari penelitian ini adalah untuk mengetahui Implementasi bimbingan berkelanjutan dalam meningkatkan kemampuan guru dalam menyusun Perangkat Pembelajaran di SMP Negeri 2 Sampoiniet Kecamatan Sampoiniet Kabupaten Aceh Jaya.

\section{KAJIAN PUSTAKA Pengertian Guru}

Rabindranath Tagore (dalam Suparlan 2005:11) menggunakan istilah Shanti Niketan atau rumah damai untuk tempat para guru mengamalkan tugas mulianya membangun spiritualitas anak-anak bangsa di India (spiritual intelligence). Pengertian guru kemudian menjadi semakin luas, tidak hanya terbatas dalam kegiatan keilmuan yang bersifat kecerdasan spiritual (spiritual intelligence) dan kecerdasan intelektual (intellectual intelligence), tetapi juga menyangkut kecerdasan kinestetik jasmaniah (bodily kinesthetic), seperti guru tari, guru olah raga, guru senam dan guru musik. Dengan demikian, guru dapat diartikan sebagai orang yang tugasnya terkait dengan upaya mencerdaskan kehidupan bangsa dalam semua aspeknya, baik spiritual dan emosional, intelektual, fisikal, maupun aspek lainnya.

Poerwadarminta (dalam Suparlan 2005:13) menyatakan, "guru adalah orang yang kerjanya mengajar." Dengan definisi ini, guru disamakan dengan pengajar. Pengertian guru ini hanya menyebutkan satu sisi yaitu sebagai pengajar, tidak termasuk pengertian guru sebagai pendidik dan pelatih. Selanjutnya Zakiyah Daradjat (dalam Suparlan 2005:13) menyatakan," guru adalah pendidik profesional karena guru telah menerima dan memikul beban dari orang tua untuk ikut mendidik anak-anak.

UU Guru dan Dosen Republik Indonesia No.14 Tahun 2005 "Guru adalah pendidik profesional dengan tugas utama mendidik, mengajar, membimbing, mengarahkan, melatih, menilai, dan mengevaluasi peserta didik pada pendidikan anak usia dini jalur pendidikan formal, pendidikan dasar, dan pendidikan menengah".

UU No.20 Tahun 2003 pasal 39 ayat 2 tentang sistem pendidikan nasional menyatakan, "pendidik merupakan tenaga profesional yang bertugas merencanakan dan melaksanakan proses pembelajaran, menilai hasil pembelajaran, melakukan pembimbingan dan pelatihan, serta melakukan penelitian dan pengabdian kepada masyarakat, terutama bagi pendidik pada perguruan tinggi." PP No.19 Tahun 2005 tentang Standar Nasional Pendidikan menyatakan, "pendidik (guru) harus memiliki kualifikasi akademik dan kompetensi sebagai agen pembelajaran, sehat jasmani dan rohani, serta memiliki kemampuan untuk mewujudkan tujuan pendidikan nasional.”

\section{Standar Kompetensi Guru}

Depdiknas (2004:4) kompetensi diartikan, "sebagai pengetahuan, keterampilan, dan nilai-nilai dasar yang direfleksikan dalam kebiasaan berpikir dan bertindak". "Secara sederhana kompetensi diartikan seperangkat kemampuan yang meliputi 
pengetahuan, sikap, nilai dan keterampilan yang harus dikuasai dan dimiliki seseorang dalam rangka melaksanakan tugas pokok, fungsi dan tanggung jawab pekerjaan dan/atau jabatan yang disandangnya" (Nana Sudjana 2009:1).

Nurhadi (2004:15) menyatakan, "kompetensi merupakan pengetahuan, keterampilan, dan nilai-nilai dasar yang direfleksikan dalam kebiasaan berpikir dan bertindak". Selanjutnya menurut para ahli pendidikan McAshan (dalam Nurhadi 2004:16) menyatakan, "kompetensi diartikan Sebagai pengetahuan, keterampilan, dan kemampuan yang dikuasai seseorang sebagai pengetahuan, keterampilan, dan kemampuan yang dikuasai seseorang yang telah menjadi bagian dari dirinya, sehingga dapat melakukan perilaku-perilaku koqnitif, afektif, dan psikomotor dengan sebaikbaiknya

Kompetensi diartikan sebagai pengetahuan, keterampilan, dan nilai-nilai dasar yang direfleksikan dalam kebiasaan berfikir dan bertindak (Dalam Suparlan). Arti lain dari kompetensi adalah spesifikasi dari pengetahuan, keterampilan, dan sikap yang dimiliki seseorang serta penerapannya di dalam pekerjaan, sesuai dengan standar kinerja yang dibutuhkan oleh lapangan.

\section{Perangkat Pembelajaran}

Perencanaan proses pembelajaran meliputi silabus Perangkat Pembelajaran . Silabus merupakan sebagian sub-sistem pembelajaran yang terdiri dari atau yang satu sama yang lain saling berhubungan dalam rangka mencapai tujuan. Hal penting yang berkaitan dengan pembelajaran adalah penjabaran tujuan yang disusun berdasarkan

Selanjutnya Oemar Hakim (dalam Kurniawati 2009:74) menyatakan, "bahwa perencanaan program pembelajaran pada hakekatnya merupakan perencanaan program jangka pendek untuk memperkirakan suatu proyeksi tentang sesuatu yang akan dilakukan dalam kegiatan pembelajaran".

Berdasarkan pendapat di atas dapat disimpulkan bahwa perencanaan pembelajaran adalah suatu upaya menyusun perencanaan pembelajaran yang akan dilaksanakan dalam kegiatan pembelajaran untuk mencapai tujuan yang telah ditetapkan dalam kurikulum sesuai dengan kebutuhan siswa, sekolah, dan daerah.

Dalam KTSP, guru bersama warga sekolah berupaya menyusun kurikulum dan perencanaan program pembelajaran, meliputi: program tahunan, program semester, silabus, dan rencana pelaksanaan pembelajaran. Rencana Pelaksanaan Pembelajaran dijabarkan dari silabus untuk mengarahkan kegiatan belajar peserta didik dalam upaya mencapai Kompetensi Dasar. perangkat pembelajaran merupakan acuan guru dalam melaksanakan pembelajaran. Oleh karena itu, apa yang tertuang di dalam perangkat pembelajaran memuat hal-hal yang langsung berkaitan dengan aktivitas pembelajaran dalam upaya pencapaian penguasaan suatu KD.

\section{Bimbingan Berkelanjutan}

Bimbingan adalah pemberian bantuan kepada individu secara berkelanjutan dan sistematis yang dilakukan oleh seorang ahli yang telah mendapat latihan khusus untuk itu,dimaksudkan agar individu dapat memahami dirinya, lingkungannya, serta dapat mengarahkan diri dan menyesuaikan diri dengan lingkungan untuk dapat 
mengembangkan potensi dirinya secara optimal untuk kesejahteraan dirinya dan kesejahteraan masyarakat.

Berdasarkan pengertian bimbingan dan berkelanjutan dapat ditarik suatu kesimpulan bahwa bimbingan berkelanjutan adalah pemberian bantuan yang diberikan seorang ahli kepada seseorang atau individu secara berkelanjutan berlangsung secara terus menerus untuk dapat mengembangkan potensi dirinya secara optimal dan mendapat kemajuan dalam bekerja.

\section{METODOLOGI PENELITIAN}

\section{Tempat dan Waktu Penelitian}

Penelitian Tindakan Sekolah ini di adakan di SMP Negeri 2 Sampoiniet Kecamatan Sampoiniet Kabupaten Aceh Jaya. PTS ini dilaksanakan pada semester genap tahun pelajaran 2019-2020 mulai 18 November s.d 19 Desember 2019

\section{Subjek Penelitian}

Subyek dalam PTS ini adalah guru bidang study di SMP Negeri 2 Sampoiniet Kecamatan Sampoiniet Kabupaten Aceh Jaya.

\section{Prosedur Penelitian}

Penelitian ini berbentuk Penelitian Tindakan Sekolah (School Action Research), yaitu sebuah penelitian yang merupakan kerjasama antara peneliti dan guru, dalam meningkatkan kemampuan guru agar menjadi lebih baik dalam menyusun rencana pelaksanaan pembelajaran

Prosedur penelitian adalah suatu rangkaian tahap-tahap penelitian dari awal sampai akhir. Penelitian ini merupakan proses pengkajian sistem berdaur sebagaimana kerangka berpikir yang dikembangkan oleh Suharsimi Arikunto dkk. Prosedur ini mencakup tahap-tahap :

(1) Perencanaan,

(2) Pelaksanaan,

(3) Pengamatan, dan

4) Refleksi.

\section{Alat Pengumpulan Data} diskusi.

Teknik pengumpulan data dalam penelitian ini adalah wawancara, observasi, dan

\section{Tekhnik Analisa Data}

Langkah-langkah yang perlu dilakukan dalam analisis data seperti ini adalah memilih data (reduksi data), mendeskripsikan data hasil temuan (memaparkan data), menarik kesimpulan hasil deskripsi.

\section{HASIL PENELITIAN DAN PEMBAHASAN \\ Hasil Observasi pada Siklus I}

Proses Pembelajaran yang dilakukan pada guru bidang study Penjaskes mulai dari kelas VII s.d IX di SMP Negeri 2 Sampoiniet Kecamatan Sampoiniet Kabupaten 
Aceh Jaya tentunya dilengkapi dengan semua perangkat pembelajaran, sebelum dilakukan penelitian semua dianjurkan membuat semua perangakat pembelajarannya.

Berdasarkan pengamatan terhadap observasi guru bidang study Penjaskes (an. Zahrannur, S.Pd), PAI (Malum Manik, S.Pd.I), dan Seni Budaya (Wirma Jita, S.Pd) pada kelas VII s.d IX, setelah dilaksanakan penelitian menunjukkan bahwa masih rendahnya kemampuan guru dalam membuat perangkat pembelajaran. Hal ini dapat dibuktikan pada tabel di bawah ini :

Tabel Nilai Observasi Guru Dalam Membuat Perangkat

Pembelajaran Tahap Siklus I

\begin{tabular}{|c|c|c|c|c|c|c|}
\hline No & Mapel & VII & VIII & IX & Rata-rata & Katagori \\
\hline 1 & Penjaskes & 65 & 60 & 65 & 64 & Kurang \\
\hline 2 & PAI & 70 & 65 & 60 & 67 & Kurang \\
\hline 3 & Seni Budaya & 60 & 60 & 65 & 64 & Kurang \\
\hline \multicolumn{2}{|c|}{ Jumlah } & $\mathbf{6 5}$ & $\mathbf{6 2}$ & $\mathbf{6 3}$ & $\mathbf{6 5}$ & Kurang \\
\hline
\end{tabular}

Tabel menunjukkan bahwa penilai guru dalam membuat perangkat masih dalam katagori kurang, dimana nilai rata-rata dari guru Penjaskes hanya mendapat nilai 65, guru PAI 62, dan guru Seni Budaya hanya 63. Hal ini menunjukkan bahwa kemampuan guru dalam membuat perangkat perlu ada perbaikan dan bimbingan pada siklus selanjutnya.

\section{Deskripsi Hasil Penelitian} Siklus I

Siklus I dilaksanakan pada tanggal 19 November 2019 s.d 21 November 2019 dengan jumlah guru mapel yaitu Penjaskes, PAI, dan Seni Budaya. Siklus I dilaksanakan dalam empat tahap, tahapan-tahapan tersebut antara lain :

a. Perencanaan

Langkah pertama yang dilakukan sebelum melaksanakan penelitian adalah mempersiapkan format wawancara kesediaan Rencana Pelaksanaan Pembelajaran (RPP) guru.

b. Pelaksanaan

Peneliti memberikan bimbingan dalam merancang dan meyusun perangkat pembelaran yang baik.

c. Pengamatan/Obeservasi

Peneliti melakukan pengamatan terhadap perangkat pembelajaran yang telah dibuat untuk memotret seberapa jauh kemampuan guru dalam menyusun perangkat pembelajaran dengan lengkap, hasil atau dampak dari tindakan yang telah dilaksanakan oleh guru dalam mencapai sasaran. Hasil rekapitulasi data tersebut dapat dilihat sebagai berikut :

Tabel Rekapitulasi Lembar Pengamatan Penyusunan Perangkat Pembelajaran Siklus I

\begin{tabular}{|c|l|c|c|c|c|c|}
\hline No & \multicolumn{1}{|c|}{ Aspek yang dinilai } & Penjas & PAI & $\begin{array}{c}\text { Seni } \\
\text { Budaya }\end{array}$ & $\begin{array}{c}\text { Rata- } \\
\text { rata }\end{array}$ & $\begin{array}{c}\text { Perentase } \\
(\%)\end{array}$ \\
\hline 1 & $\begin{array}{l}\text { Kemampuan } \\
\text { mengembangkan }\end{array}$ & 4 & 3 & 3 & 3 & $60 \%$ \\
\hline
\end{tabular}




\begin{tabular}{|c|c|c|c|c|c|c|}
\hline & indikator & & & & & \\
\hline 2 & $\begin{array}{l}\text { Kemampuan } \\
\text { merumuskan tujuan } \\
\text { pembelajaran }\end{array}$ & 4 & 4 & 4 & 4 & $65 \%$ \\
\hline 3 & $\begin{array}{l}\text { Kemampuan dalam } \\
\text { menentukan } \\
\text { materi/bahan ajar }\end{array}$ & 3 & 4 & 3 & 3 & $60 \%$ \\
\hline 4 & $\begin{array}{l}\text { Kemampuan dalam } \\
\text { menentukan sumber } \\
\text { belajar }\end{array}$ & 3 & 3 & 3 & 3 & $60 \%$ \\
\hline 5 & $\begin{array}{l}\text { Kemampuan menetukan } \\
\text { metode pembelajaran }\end{array}$ & 3 & 3 & 4 & 3 & $60 \%$ \\
\hline 6 & $\begin{array}{l}\text { Kemampuan } \\
\text { menetunkan media } \\
\text { pembelajaran }\end{array}$ & 4 & 2 & 3 & 3 & $60 \%$ \\
\hline 7 & $\begin{array}{l}\text { Kemampuan menetukan } \\
\text { penilaian }\end{array}$ & 3 & 3 & 3 & 3 & $60 \%$ \\
\hline
\end{tabular}

Rekapitulasi data pengamatan guru di atas dapat diketahui bahwa pengamatan terhadap persentase kemampuan guru dalam menyusun perangkat pembelajaran hanya $60 \%$.

d. Refleksi Siklus I

Berdasarkan hasil pengamatan Peneliti mengkaji, melihat, dan mempertimbangkan hasil atau dampak dari tindakan yang telah dilakukan. Berdasarkan hasil dari refleksi ini, peneliti bersama guru melaksanakan revisi atau perbaikan terhadap perangkat pembelajaran yang telah disusun agar sesuai dengan rencana awal yang mungkin saja masih bisa sesuai dengan yang peneliti inginkan.

\section{Siklus II}

Hasil penelitian pada siklus I belum memuaskan dan belum mencapai indikator keberhasilan yang ditentukan peneliti, maka dilanjutkan ke siklus II yang dilaksanakan pada tanggal 26 November s.d 02 Desember 2019, dengan jumlah guru yang sama yaitu guru Penjaskes, PAI, dan Seni Budaya.

Tahapan-tahapan pada siklus II sama dengan tahapan yang dilakukan pada siklus I, Cuma pada siklus II ini adalah : menyelidiki kembali hasil perbaikan guru dalam menyusun semua perangkat pembelajaran.

Hasil rekapitulasi data tersebut dapat dilihat sebagai berikut :

\section{Tabel Rekapitulasi Lembar Pengamatan Penyusunan}

Perangkat Pembelajaran Siklus II

\begin{tabular}{|c|l|c|c|c|c|c|}
\hline No & \multicolumn{1}{|c|}{ Aspek yang dinilai } & Penjas & PAI & $\begin{array}{c}\text { Seni } \\
\text { Budaya }\end{array}$ & $\begin{array}{c}\text { Rata- } \\
\text { rata }\end{array}$ & $\begin{array}{c}\text { Perentase } \\
\text { (\%) }\end{array}$ \\
\hline 1 & $\begin{array}{l}\text { Kemampuan } \\
\text { mengembangkan indikator }\end{array}$ & 4 & 4 & 4 & 4 & $100 \%$ \\
\hline 2 & $\begin{array}{l}\text { Kemampuan merumuskan } \\
\text { tujuan pembelajaran }\end{array}$ & 4 & 4 & 4 & 4 & $100 \%$ \\
\hline
\end{tabular}




\begin{tabular}{|c|l|c|c|c|c|c|}
\hline 3 & $\begin{array}{l}\text { Kemampuan dalam } \\
\text { menentukan materi/bahan } \\
\text { ajar }\end{array}$ & 4 & 4 & 4 & 4 & $100 \%$ \\
\hline 4 & $\begin{array}{l}\text { Kemampuan dalam } \\
\text { menentukan sumber belajar }\end{array}$ & 4 & 4 & 4 & 4 & $100 \%$ \\
\hline 5 & $\begin{array}{l}\text { Kemampuan menetukan } \\
\text { metode pembelajaran }\end{array}$ & 4 & 4 & 4 & 4 & $100 \%$ \\
\hline 6 & $\begin{array}{l}\text { Kemampuan menetunkan } \\
\text { media pembelajaran }\end{array}$ & 4 & 4 & 4 & 4 & $100 \%$ \\
\hline 7 & $\begin{array}{l}\text { Kemampuan menetukan } \\
\text { penilaian }\end{array}$ & 4 & 4 & 4 & 4 & $100 \%$ \\
\hline
\end{tabular}

Rekapitulasi data pengamatan guru di atas dapat diketahui bahwa pengamatan terhadap kemampuan guru dalam menyusun perangkat pada siklus II diperoleh skor persentase $100 \%$ pada kategori baik.

\section{Pembahasan}

Dengan kerjasama antara peneliti dengan dewan guru dalam melakukan bimbingan terhadap menyusun perangkat pembelajaran akan menghasilkan hasil yang baik. Hasil kemampuan guru dalam menyusun perangkat pembelajaran meningkat dari setiap siklusnya, hal ini dapat dibuktikan dengan rekapitulasi data perbandingan antara siklus I dan siklus II sebagai berikut :

Tabel Rekapitulasi Lembar perbandingan Pengamatan Penyusunan Perangkat Pembelajaran antara siklus I dan Siklus II

\begin{tabular}{|c|c|c|c|c|c|c|c|}
\hline Nama Guru & \multicolumn{7}{|c|}{ Aspek yang dinilai } \\
\hline $\begin{array}{l}\text { Zahrannur, } \\
\text { S.Pd }\end{array}$ & $\begin{array}{l}\text { Kemampuan } \\
\text { mengembang } \\
\text { kan indikator }\end{array}$ & $\begin{array}{l}\text { Kemam } \\
\text { puan } \\
\text { merumu } \\
\text { skan } \\
\text { tujuan } \\
\text { pembela } \\
\text { jaran }\end{array}$ & $\begin{array}{l}\text { Kemam } \\
\text { puan } \\
\text { dalam } \\
\text { menentu } \\
\text { kan } \\
\text { materi/ } \\
\text { bahan } \\
\text { ajar }\end{array}$ & $\begin{array}{l}\text { Kemam } \\
\text { puan } \\
\text { dalam } \\
\text { menent } \\
\text { ukan } \\
\text { sumber } \\
\text { belajar }\end{array}$ & $\begin{array}{l}\text { Kemam } \\
\text { puan } \\
\text { menetu } \\
\text { kan } \\
\text { metode } \\
\text { pembela } \\
\text { jaran }\end{array}$ & $\begin{array}{l}\text { Kemam } \\
\text { puan } \\
\text { menetun } \\
\text { kan } \\
\text { media } \\
\text { pembela } \\
\text { jaran }\end{array}$ & $\begin{array}{l}\text { Kemampu } \\
\text { an } \\
\text { menetukan } \\
\text { penilaian }\end{array}$ \\
\hline Siklus I & 4 & 4 & 3 & 3 & 3 & 4 & 3 \\
\hline Siklus II & 4 & 4 & 4 & 4 & 4 & 4 & 4 \\
\hline $\begin{array}{c}\text { Nama } \\
\text { Guru } \\
\text { PAI }\end{array}$ & \multicolumn{7}{|c|}{ Aspek yang dinilai } \\
\hline $\begin{array}{l}\text { Malum } \\
\text { Manik, } \\
\text { S.Pd.I }\end{array}$ & $\begin{array}{l}\text { Kemampuan } \\
\text { mengemban } \\
\text { gkan } \\
\text { indikator }\end{array}$ & $\begin{array}{l}\text { Kemam } \\
\text { puan } \\
\text { merumu } \\
\text { skan } \\
\text { tujuan } \\
\text { pembela } \\
\text { jaran }\end{array}$ & $\begin{array}{l}\text { Kemam } \\
\text { puan } \\
\text { dalam } \\
\text { menentu } \\
\text { kan } \\
\text { materi/b } \\
\text { ahan ajar }\end{array}$ & $\begin{array}{l}\text { Kema } \\
\text { mpuan } \\
\text { dalam } \\
\text { menent } \\
\text { ukan } \\
\text { sumber } \\
\text { belajar }\end{array}$ & $\begin{array}{l}\text { Kemam } \\
\text { puan } \\
\text { menetu } \\
\text { kan } \\
\text { metode } \\
\text { pembela } \\
\text { jaran }\end{array}$ & $\begin{array}{l}\text { Kemam } \\
\text { puan } \\
\text { menetun } \\
\text { kan } \\
\text { media } \\
\text { pembela } \\
\text { jaran }\end{array}$ & $\begin{array}{l}\text { Kemampu } \\
\text { an } \\
\text { menetukan } \\
\text { penilaian }\end{array}$ \\
\hline
\end{tabular}




\begin{tabular}{|c|c|c|c|c|c|c|c|}
\hline Siklus I & 3 & 4 & 4 & 3 & 3 & 2 & 3 \\
\hline Siklus II & 4 & 4 & 4 & 4 & 4 & 4 & 4 \\
\hline $\begin{array}{c}\text { Nama } \\
\text { Guru } \\
\text { Seni } \\
\text { Budaya }\end{array}$ & \multicolumn{7}{|c|}{ Aspek yang dinilai } \\
\hline $\begin{array}{l}\text { Wirma } \\
\text { Jita, S.Pd }\end{array}$ & $\begin{array}{l}\text { Kemampuan } \\
\text { mengemban } \\
\text { gkan } \\
\text { indikator }\end{array}$ & $\begin{array}{l}\text { Kemam } \\
\text { puan } \\
\text { merumu } \\
\text { skan } \\
\text { tujuan } \\
\text { pembela } \\
\text { jaran }\end{array}$ & $\begin{array}{l}\text { Kemam } \\
\text { puan } \\
\text { dalam } \\
\text { menentu } \\
\text { kan } \\
\text { materi/b } \\
\text { ahan ajar }\end{array}$ & $\begin{array}{l}\text { Kema } \\
\text { mpuan } \\
\text { dalam } \\
\text { menent } \\
\text { ukan } \\
\text { sumber } \\
\text { belajar }\end{array}$ & $\begin{array}{l}\text { Kemam } \\
\text { puan } \\
\text { menetu } \\
\text { kan } \\
\text { metode } \\
\text { pembela } \\
\text { jaran }\end{array}$ & $\begin{array}{l}\text { Kemam } \\
\text { puan } \\
\text { menetun } \\
\text { kan } \\
\text { media } \\
\text { pembela } \\
\text { jaran }\end{array}$ & $\begin{array}{l}\text { Kemampu } \\
\text { an } \\
\text { menetukan } \\
\text { penilaian }\end{array}$ \\
\hline Siklus I & 3 & 4 & 3 & 3 & 3 & 3 & 3 \\
\hline Siklus II & 4 & 4 & 4 & 4 & 4 & 4 & 4 \\
\hline
\end{tabular}

Pada siklus I hasil kemampuan guru masih dibawah rata-rata hanya sebesar $60 \%$ sementara pada sikus II dapat diketahui bahwa terjadi peningkatan jumlah persentase yang mencapai $100 \%$.

Target ketuntasan tersebut dapat digambarkan dalam diagram di bawah ini :

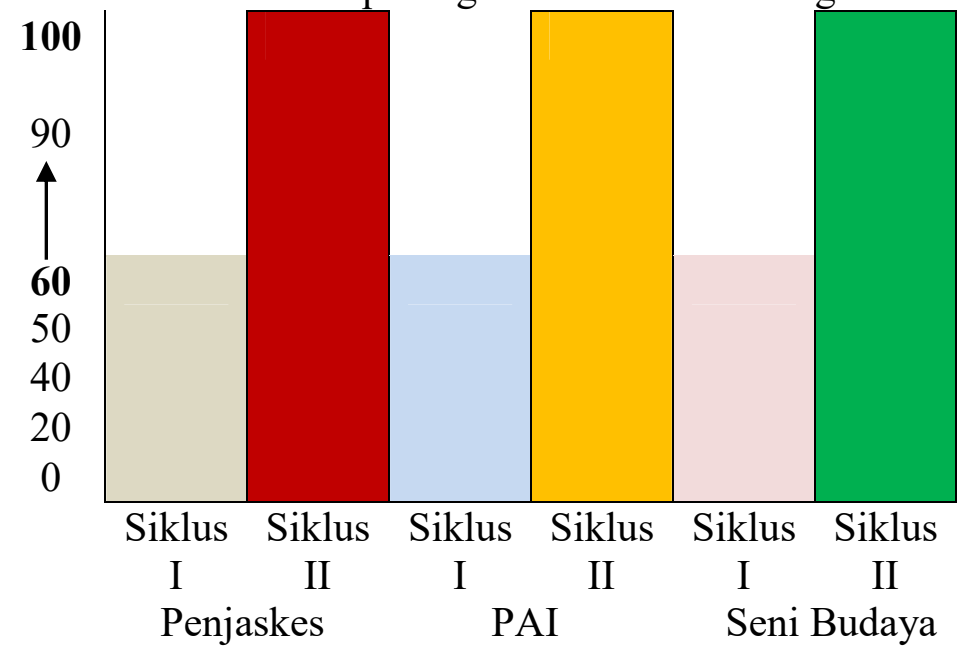

Gambar 1 Persentase siklus I dan siklus II

Persentase ketuntasan yang diperoleh pada setiap siklusnya juga mengalami peningkatan. Kriteria ketuntasan klasikal yang digunakan peneliti adalah apabila persentase ketuntasan klasikal mencapai maka penelitian dapat dikatakan berhasil.

Kriteria ketuntasan dinyatakan dengan nilai $4(100 \%)$, sementara pada siklus I hanya mendapat reratanya $3(60 \%)$ dan pada siklus II persentase meningkat menjadi $(100 \%)$ karena sudah mendapat nilai 4.

\section{Kesimpulan}

Berdasarkan hasil penelitian yang dilakukan di SMP Negeri 2 Sampoiniet Kecamatan Sampoiniet Kabupaten Aceh Jaya, dapat disimpulkan yaitu meningkatkan kemampuan guru dalam menyusun perangkat pembelajaran dengan diadakan 
pengamatan terhadap perangkat pembelajaran guru. Kemampuan guru dalam menyusun Rencana Pelaksanaan Pembelajaran (RPP) dapat dicermati melalui kemampuannya dalam merancang setiap komponen pembelajaran secara terpadu. Komponen pembelajaran yang dimaksud meliputi: pengembangan indikator; penentuan tujuan pembelajaran; penentuan materi/bahan ajar; penentuan sumber belajar; penentuan metode pembelajaran; penentuan media pembelajaran; dan penilaian, hal ini perlu di asah terus-menurus sehingga proses pembelajaran yang dilakukan guru agar menciptakan pembaharuan menuju kearah pendidikan yang maju dan bermutu.

\section{DAFTAR PUSTAKA}

Dewi, Kurniawati Eni . 2009. Pengembangan Bahan Ajar Bahasa Dan Sastra Indonesia Dengan Pendekatan Tematis. Tesis. Surakarta: Program Pascasarjana Universitas Sebelas Maret.

Depdiknas. 2003. UU RI No. 20 Tahun 2003 tentang Sistem Pendidikan Nasional. Jakarta: Depdiknas. 2004. Standar Kompetensi Guru Sekolah Dasar. Jakarta: Depdiknas. 2005. UU RI No. 14 Tahun 2005 tentang Guru dan Dosen. Jakarta: Depdiknas. 2005. Standar Nasional Pendidikan. Jakarta: Depdiknas. 2007. Permendiknas RI No. 41 Tahun 2007a tentang Standar Proses. Jakarta: Depdiknas.

Nurhadi. 2004. Kurikulum 2004. Jakarta: PT Gramedia Widiasarana Indonesia.

Pidarta, Made . 1992. Pemikiran Tentang Supervisi Pendidikan. Jakarta: Bumi Aksara.

Sudjana, Nana. 2009. Standar Kompetensi Pengawas Dimensi dan Indikator. Jakarta : Binamitra Publishing.

Suparlan. 2005. Menjadi Guru Efektif. Yogyakarta: Hikayat Publishing. 2006. Guru Sebagai Profesi. Yogyakarta: Hikayat Publishing. Tim Redaksi Kamus Besar Bahasa Indonesia. Edisi kedua 